\title{
Performance characteristics and blood profile of rams fed mixture of bamboo (Bambusa vulgaris) leaves and neem (Azadirachta indica) seed cake
}

\author{
* Okoruwa, 'M. I., Adewumi, M. K². and Ikhimioya, I.
}

'Department of Animal Science, Ambrose Alli University, P. M. B. 14. Ekpoma, Edo State, Nigeria. ${ }^{2}$ Department of Animal Science, University of Ibadan, Ibadan Nigeria.

*Corresponding E-mail: odionokos@yahoo.com or okosmich@gmail.com.

\section{Abstract}

The study was carried out to assess the performance characteristics and blood profile of growing rams fed mixture of bamboo leaves and neem seed cake. Eighteen West African dwarf rams with an average weight of $8.00 \pm 0.20 \mathrm{~kg}$ and aged between $8-9$ months were randomly allotted to three dietary treatments with six animals per treatment group in a completely randomized design. The diets compared were TD, $(70 \%$ Guinea grass with $30 \%$ concentrate diet which was the control group), $T D_{2}$ (mixture of $50 \%$ bamboo leaves with $20 \%$ neem seed cake and $30 \%$ concentrate diet) and $T D_{3}$ (combination of $45 \%$ bamboo leaves with $25 \%$ neem seed cake and $30 \%$ concentrate diet). The results obtained indicated that average total feed intake (11.13kg), average daily feed intake $(132.50 \mathrm{~g})$, mean corpuscular haemoglobin concentration $(33.35 \mathrm{~g} / \mathrm{dL})$, glucose $(59.0 \mathrm{Img} / \mathrm{dL})$, cholesterol $(42.89 \mathrm{mg} / \mathrm{dL})$, creatinine $(1.01 \mathrm{mg} / \mathrm{dL})$ and urea $(13.73 \mathrm{mg} / \mathrm{dL})$ were significantly $(P<0.05)$ better with animals on $T D_{1}$. Animals on $T D_{2}$ had the highest values in terms of finial body weight (11.33 kg), average total weight gain (3.27 kg), average daily weight gain (38.93g), total digestible nutrient $(68.97 \%)$, packed cell volume $(30.06 \%)$, haemoglobin $(10.68 \mathrm{~g} / \mathrm{dl})$, red blood cell $\left(9.42 \times 10^{6} \% \mathrm{ml}\right)$, mean corpuscular haemoglobin (11.70Pg), total protein $(8.09 \mathrm{~g} / \mathrm{dL})$, albumin $(3.03 \mathrm{~g} / \mathrm{dL})$, and globulin $(5.06 \mathrm{~g} / \mathrm{dL})$. Feed conversion ratio (4.27), mean corpuscular volume $(30.95 \mathrm{fl})$ and white blood cell $\left(2.56 \times 10^{3} / \mathrm{mL}\right)$ were significantly highest for animals on $T D_{3}$. No significant $(P>0.05)$ difference existed between the experimental rams with regards to initial body weight, lymphocyte, neutrophile. It was concluded that combination of $50 \%$ bamboo leaves with $20 \%$ of neem seed cake and $30 \%$ concentrate diet improved performance, haematological and serum biochemical indices for growing rams.

Keywords: bamboo leaves, neem seed cake, performance, blood, ram

\section{Introduction}

The tremendous increase in human population coupled with the high standard of living has placed considerably pressure on the existing conventional livestock feed resources. The competition between man and livestock for these conventional feed resources as well as scarcity of forage grasses in the dry season has been a major constraint militating against the increase in production of animal protein from ruminants. The potential of ruminant production in alleviating the low animal protein intake in Nigeria and other developing countries especially those in the tropics need no emphasis (Ahamefule and Udo, 2010). Attempts to alleviate this problem by searching for potential feed resources, have led to urgent need to source for alternative feedstuff within the localities for incorporation into the diet of ruminant animals at a least cost. However, Agiang et 


\section{Performance and blood profile of rams fed mixture of bamboo leaves and neem seed cake}

al. (2004) suggested that such alternative feedstuff should not be in great demand as human food or industrial use. Besides, they should be readily available and not be subjected to the dictates of season.

In recent years, there has been a growing interest in many tropical countries to identify potentially important feed sources among non-conventional feeds and lesserknown types and grasses for inclusion in the ruminant diet to provide rations that are sufficient in energy and protein to supplement or replace the available low nutrient forages during the off season. Bamboo (Bambusa vulgaris) leaves and neem (Azadirachta indica) seed cake have been recognised as some of the most lesserknown feed ingredients to improve animal performance in smallholder ruminant livestock production. Bamboo is a grass with a woody stem that belongs to the family of poaceae. It is a major non-timber forest product which if properly harnessed should provide rural people with sufficient food and fodder for their livestock and generate income (ITTO, 2009). Bamboo leaves are rich in energy, protein, phosphorus and vitamin $\mathrm{A}$, which are the principal components that may be limiting in other grasses on rangelands. The major limiting factor in using bamboo leaves as forage is the inherent content of the leaves that is affected by leaf age, plant age and the position of the leaf. Though, there are few documented evidences on the use of bamboo leaves as fodder in ruminant nutrition, literature (Antwi-Boasiako et al.,2011) reported that bamboo leaves are rich in nitrogenous material and excellent source of vitamin $\mathrm{A}$ which are valuable feed for cattle and horses if combined with other relatively known feedstuff such as neem seed cake. Neem seed cake obtained from need seed oil industry is a non-conventional feedstuff for livestock. Need plant is native to India with only species in the genus Azardirachta, which belongs to the family of meliceae. Its medicinal properties are well documented making it a desirable tree plant (Adjorlolo et al., 2016). Neem seed has great potentials for livestock production, thus it has been reported to be relative balanced in protein and rich in mineral profiles (Aruwayo et al., 2011). The major limiting factors of need seed as livestock feed ingredient include neem oil, bitterness and toxic triterpenoids which are mainly nimbin, nimbidin, azadirachtin and salanin (Bawa et al., 2005). Thus, processing that require oil extraction and detoxification to reduce the oil and antinutritional factors are important to obtain neem seed cake. The need therefore arises to investigate the use of bamboo leaves with neem seed cake as replacement for guinea grass with a view to provide information which could be employed for ruminant livestock nutrition in developing countries where livestock feeds security is not certain. Thus, the study was therefore designed to assess the performance characteristics and blood profile of growing rams fed bamboo (Bambusa vulgaris) leaves with neem seed cake.

\section{Materials and Methods Site location}

This research was conducted at the Teaching and Research Farm of Ambrose Alli University, Ekpoma, Nigeria. The site was located on longitude $6.09^{\circ} \mathrm{E}$ and Latitude $6.42^{\circ} \mathrm{N}$ and with a temperature range of between $26^{\circ} \mathrm{C}$ and $34^{\circ} \mathrm{C}$. The mean annual rainfall was about $1556 \mathrm{~mm}$.

\section{Experimental diets and animals}

Guinea grass (Panicum maximum) and bamboo (Bambusa vulgaris) leaves were harvested within the livestock farm. The neem seed were collected in batches during fruiting season. Neem fruits were soaked in 


\section{Okoruwa, Adewumi and Ikhimioya}

water for five days and de-pulped using a de-pulper machine. The seeds and pulp were then washed and sundried for ten days. The dried seeds were decorticated using a winnowing machine. Thereafter, the neem seed kernels were crushed before steamed and the oil was expelled using expeller machine. The concentrate supplement that comprised $80 \%$ wheat offal, $18 \%$ brewer dried grain, $0.75 \%$ oyster shell, $0.5 \%$ bone meal, $0.05 \%$ salt and $0.25 \%$ vitamin premix was purchased at a feedmill in Benin City. The diets consist of basal and concentrate supplement which were offered at the rate of $5 \%$ of their body weight in a ratio of 70:30 respectively. Guinea grass and bamboo leaves with neem seed cake constituted the basal diets. Dietary treatments comprised; TD, (solely on 70\% guinea grass as basal diet, which was the control group), $\mathrm{TD}_{2}$ (combination of $50 \%$ bamboo leaves with $20 \%$ neem seed cake as basal diet) and $\mathrm{TD}_{3}$ (consisted of $45 \%$ bamboo leaves with $25 \%$ neem seed cake as basal diet). Concentrate supplement of $30 \%$ was added to all the three dietary treatments respectively. Eighty healthy West African dwarf growing rams purchased from local livestock market at Ekpoma were used in this study. The ram-lambs were between 8-9 months old with an average weight of $8.00 \pm$ $0.20 \mathrm{~kg}$. They were randomly allotted to the three dietary treatment groups $\left(T_{1}, T_{2}\right.$ and $T_{3}$ ) with replicates of six animals per treatment group in a completely randomized design.

\section{Management and feeding}

Prior to the commencement of this experiment, pens were cleaned and disinfected; animals were vaccinated against the common viral diseases and dewormed against the helminthes. Animals were housed individually in dwarf wall pens with concrete floors and roofed with asbestos sheets. Experimental diets were offered once daily at about $8.00 \mathrm{am}$ to the animals. The animals equally had free access to water and mineral salt lick. Feeds offered and leftovers were measured daily in the morning prior to feeding and watering to determine daily feed intake. Animals were weighed at the commencement of the study before administering the experimental diets. Subsequently, live weight measurement were carried out on weekly basis to determine weight changes. Feed conversion ratio was calculated as the ratio of feed intake over the body weight gain. The experiment lasted for 84 days.

\section{Digestibility}

At the end of the growth study, total digestible nutrient (TDN) was carried out on the sheep. The sheep were kept off-feeds for 12 hours but with water supplied constantly; this was to evacuate their gut of the residual feeds eaten. Fresh feeds of known weight were then given to the sheep. The quantity of feeds offered which represented the fraction of feeds given to each sheep per day and the leftover which represented the one that was not consumed were weighed daily. The weight difference between them was recorded and taken as the feed intake. Faecal samples were also collected and weighed daily. However, the process of samples collection lasted for 7 days. Thereafter, sub-samples of each replicate faecal sample were bulked together before they were stored separately in airtight container and frozen until required for analysis.

Thus, total digestible nutrient (TDN) was calculated using this formula;

$T D N=$ Digestible crude protein + Digestible crude fibre $+2.25 \mathrm{X}$ digestible ether extract + Digestible nitrogen free extract. 


\section{Blood collection}

On the last day of the feeding trial period, experimental animals were fasted over night and blood was collected in the morning. Two sets of blood samples were collected from all the experimental animals from the jugular vein using sterile disposable $10 \mathrm{~mL}$ needles of 20 gauge and syringes. A set of the blood samples $(5 \mathrm{~mL})$ was collected and transferred immediately into plastic tubes containing the anticoagulant ethylene diamine tetra acetic acid for haematological study. Another set of the blood samples $(5 \mathrm{~mL})$ was collected into sterile anti-coagulant free plastic tubes and centrifuged at $3000 \mathrm{rpm}$ for 15 minutes to separate the plasma. The separated plasma was then transferred into previously numbered plastic vials with the help of automatic micro-lit pipette capped and preserved at $-20^{\circ} \mathrm{C}$ for further analysis. For serum separation, the supernatant serum was carefully aspirated, placed in a clean labelled plastic vial and stored in deep freezer for further assay to determine serum biochemical indices.

\section{Laboratory and statistical analyses}

The proximate compositions of the basal diets and concentrate supplement offered to the animals and faecal samples were determined according to the procedures of AOAC (1990). The haematological parameters determined were packed cell volume $(\mathrm{PCV})$ and haemoglobin $(\mathrm{Hb})$ concentration following the procedures outlined by Schalm et al. (1975). Red blood cell (RBC) and white blood cell (WBC) with their differential counts were determined by using the haemocytometer. Mean Corpuscular Volume (MCV), Mean Corpuscular Haemoglobin $(\mathrm{MCH})$ and Mean Corpuscular Haemoglobin Concentration (MCHC) were calculated according to standard formulae (Jain, 1986). Biochemical components of the
Serum samples estimated were total protein, albumin, globulin, glucose, cholesterol, creatinine and Urea using the methods described by other researchers (Ogunsanmi et al., 1984; Ikhimioya and Imasuen, 2007).

Data generated from growth, total digestible nutrient (TDN), haematological and serum biochemical parameters were subjected to analysis of variance (ANOVA) and significant differences between means were separated using the Duncan's Multiple Range Test (SAS, 1999).

\section{Results and Discussion}

Table 1 presents proximate composition of Guinea grass (GG), bamboo leaves (BL), neem seed cake (NSC) and concentrate supplement (CS) of the experimental diets. Dry matter values were generally high 'except for Guinea grass that was slightly above average value. The stage at which the GG was harvested could probably affect the dry matter content. The crude protein value for GG was low but high in crude fibre. Thus, the need to combine with concentrate supplement in the diets was necessary to supply fermentable carbohydrate and protein to balance the supplied nutrient from the GG and encourage rumen degradation as well as to promote production (Yousuf and Adeloye, 2011). Ether extract values that ranged between 1.06 and $7.54 \%$ were highest in NSC and lowest in CS. The NSC had the lowest value of crude fibre, hence it was combined with bamboo leaves to increase the fibre content in the test diets. The highest value of ash obtained in BL indicated that bamboo leaves were highest in mineral supply in the treatment diets than other feed ingredients. Nitrogen free extract obtained in the feedstuffs varied from 31.85 to $57.16 \%$ with CS recorded that highest and $\mathrm{BL}$ the lowest. The proximate compositions of NSC recorded 


\section{Okoruwa, Adewumi and Ikhimioya}

in this study were consistent with the report of Bawa et al. (2007). The BL proximate

composition of the study was lower than the values reported by Zehui (2007).

Table 1: Proximate Composition (\%DM basis) of guinea grass, test feeds and concentrate supplement offered to the experimental growing rams.

\begin{tabular}{lcccc}
\hline \multirow{2}{*}{ Nutrient } & \multicolumn{3}{c}{ Feeds } \\
\cline { 2 - 5 } & GG & BL & NSC & CS \\
\hline Dry Matter & 68.99 & 89.66 & 96.65 & 84.42 \\
Crude protein & 7.95 & 18.40 & 23.88 & 20.78 \\
Ether extract & 4.00 & 1.52 & 7.54 & 1.06 \\
Crude fibre & 31.00 & 27.06 & 5.44 & 13.00 \\
Ash & 8.90 & 10.83 & 5.69 & 8.00 \\
Nitrogen free extract & 48.15 & 31.85 & 44.55 & 57.16 \\
\hline
\end{tabular}

$\mathrm{GG}=$ Guinea grass, $\mathrm{BL}=$ Bamboo leaves, $\mathrm{NSC}=$ Neem seed cake, $\mathrm{CS}=$ Concentrate Supplement

Growth indices of growing rams as influenced by treatment diets is shown in Table 2. Final body weight values of 10.94 , 11.33 and $10.81 \mathrm{~kg}$ recorded for growing rams on $\mathrm{TD}_{1}, \mathrm{TD}_{2}$ and $\mathrm{TD}_{3}$ respectively were statistically differed $(\mathrm{P}<0.05)$ between treatment diets. Higher numerical values were obtained in rams on $\mathrm{TD}_{2}$ compared with $\mathrm{TD}_{1}$ and $\mathrm{TD}_{3}$. This could be an indication of a good nutritive value of the test diet (bamboo leaves and neem seed cake) and their combination ratios that were optimally utilized by the rams. This lends support from the report of Odunsi et al. (2009) that the diet that is optimally utilized by animals has a positive effect on the final body weight of the animals. Average total weight gain for rams on treatment diets $\mathrm{TD}_{\text {, }}$ $(2.71 \mathrm{~kg})$ and $\mathrm{TD}_{3}(2.50 \mathrm{~kg})$ were not significantly $(P>0.05)$ different from one another but $\mathrm{TD}_{2}(3.27 \mathrm{~kg})$ was significantly higher $(P<0.05)$ than the two treatment diets. However, the numerical increased values in average total weight gain for rams with corresponding increase in inclusion level of bamboo leaves and decrease level of neem seed cake in the diet $\left(\mathrm{TD}_{2}\right)$ might ascribed to the nutrient density and availability that was efficiently utilized which eventually translated to the improvement in growth rate. This fact support the findings of some workers (Ogbuewu et al., 2011; Adjorlolo et al., 2016) who reported that when diets of ruminant animals consist of a mixed forage and lesser neem seed cake regime, higher weight gain is obtained than when diets consist of neem seed cake alone. Average daily weight gain of rams were significantly $(\mathrm{P}<0.05)$ affected by dietary treatments. Rams fed increased level of neem seed cake with decreased inclusion level of bamboo leaves diet $\left(\mathrm{TD}_{3}, 29.76 \mathrm{~g}\right)$ had a significant $(\mathrm{P}<0.05)$ depressed daily weight gain compared to those on diets $\mathrm{TD}_{1}(32.26 \mathrm{~g})$ and $\mathrm{TD}_{2}(38.93 \mathrm{~g})$. The depressed weight gain observed in rams on $\mathrm{TD}_{3}$ could be attributed to the residual anti-nutritional factors of the neem seed cake and high level of bitter principles inherent in the diet which did not prevent tissue depletion in rams. Authors (Ghimeray et al., 2009; Bawa et al., 2007; Odunsi et al., 2009), had reported that several feeding trials with higher levels of neem seed cake (above 30\%) have revealed poor palatability and adverse effect on growth performance among different categories of livestock and poultry with ruminants tolerating reasonably levels of the neem seed cake than the monogastrics. 
Performance and blood profile of rams fed mixture of bamboo leaves and neem seed cake

Table 2: Growth indices and total digestible nutrients of growing rams fed experimental diets

\begin{tabular}{lllll}
\multirow{2}{*}{ Parameters } & \multicolumn{3}{c}{ Treatments } & SEM \pm \\
\cline { 2 - 5 } & TD $_{1}$ & TD $_{2}$ & TD $_{3}$ & \\
\hline Initial body weight $(\mathrm{kg})$ & 8.23 & 8.06 & 8.31 & 0.03 \\
Finial body weight $(\mathrm{kg})$ & $10.94^{\mathrm{b}}$ & $11.33^{\mathrm{a}}$ & $10.81^{\mathrm{b}}$ & 0.07 \\
Av. total weight gain $(\mathrm{kg})$ & $2.71^{\mathrm{b}}$ & $3.27^{\mathrm{a}}$ & $2.50^{\mathrm{b}}$ & 0.01 \\
Av. daily weight gain $(\mathrm{g})$ & $32.26^{\mathrm{b}}$ & $38.93^{\mathrm{a}}$ & $29.76^{\mathrm{b}}$ & 0.12 \\
Av. Total feed intake $(\mathrm{kg})$ & $11.13^{\mathrm{a}}$ & $10.89^{\mathrm{b}}$ & $10.67^{\mathrm{b}}$ & 0.13 \\
Av. daily feed intake (g) & $132.50^{\mathrm{a}}$ & $129.64^{\mathrm{b}}$ & $127.02^{\mathrm{c}}$ & 0.10 \\
Feed conversion ratio (FCR) & $4.11^{\mathrm{a}}$ & $3.33^{\mathrm{b}}$ & $4.27^{\mathrm{b}}$ & 0.04 \\
Total digestible nutrient (\%) & $63.99^{\mathrm{b}}$ & $68.97^{\mathrm{a}}$ & $65.97^{\mathrm{b}}$ & 0.20 \\
\hline AV= Average & & & &
\end{tabular}

a,b.c. Means bearing superscript in the same row differ significantly $(P<0.05)$

$\mathrm{SEM} \pm=$ Standard error of mean

Average total feed intake of growing rams fed experimental diets had significant $(\mathrm{P}<$ $0.05)$ differences across dietary treatments. Rams fed treatment diets $\mathrm{TD}_{2}(10.89 \mathrm{~kg})$ and $\mathrm{TD}_{3}(10.67 \mathrm{~kg})$ had the least total feed intake compared to those fed on $\mathrm{TD}_{1}(11.13 \mathrm{~kg})$ which was the control group. This could probably due to the neem seed pungent smell and poor palatability, which depressed feed consumption and adversely affected daily feed intake. This observation corroborates the report of Gowda and Sastry (2000) that neem seed cake is toxic and bitter to taste due to triterpenoids, which restricts its safe inclusion in livestock diets. In the same vein, they further reported that lower feed intake, nutrient digestibility and growth were observed in rabbits fed $20 \%$ raw neem seed meal. The average daily feed intake that ranged between 127.02 and $132.50 \mathrm{~g}$ decreased with increased in inclusion levels of neem seed cake in the diet. The significant $(\mathrm{P}<0.05)$ decline in feed intake registered in rams on $\mathrm{TD}_{3}$ could be linked with poor presentation of the neem seed cake due to its blackish colour in addition to its bitter taste which hitherto affected on the filling on the gastro intestinal tract at faster rate. This is in consonance with the study conducted by Chandrawathani et al. (2006) who reported that physical presentation of feed and its poor biological value contribute to less feed consumption and lesser weight gain in livestock.

Feed conversion ratio of rams fed TD, (4.11) and $\mathrm{TD}_{3}(4.27)$ showed no significant $(\mathrm{P}>0.05)$ difference compared to those fed on $\mathrm{TD}_{2}$ (3.33). The low feed conversion ratio of rams maintained on $\mathrm{TD}_{2}$ could be ascribed to the quality of nutrient which was capable of increasing feed efficiency and growth rate. Thus rams on $\mathrm{TD}_{2}$ efficiently utilized their feed better than those treatment diets $\mathrm{TD}_{1}$ and $\mathrm{TD}_{3}$. This further attest the comparable growth performance observed in rams on $\mathrm{TD}_{2}$. However, the variation observed in respect to total digestible nutrient (TDN) that ranged between 63.99 and $68.98 \%$ were significantly $(\mathrm{P}<0.05)$ different among treatment diets. This disparity might be due to the degree of digestibility of nutrient in the diets. Nevertheless, the higher values obtained in all the dietary treatments was an evidence that the diets were acceptable to the rams without detrimental effect. 
Okoruwa, Adewumi and Ikhimioya

Table 3: Haematological parameters of growing rams fed mixture of bamboo leaves and neem seed cake as replacement for forage grass.

\begin{tabular}{lllll}
\hline \multirow{2}{*}{ Parameters } & \multicolumn{3}{c}{ Treatments } & \multirow{2}{*}{ SEM \pm} \\
\cline { 2 - 4 } & TD $_{\mathbf{1}}$ & TD $_{2}$ & TD $_{3}$ & \\
\hline Packed cell volume $(\%)$ & $26.08^{\mathrm{b}}$ & $30.06^{\mathrm{a}}$ & $27.93^{\mathrm{c}}$ & 0.09 \\
Haemoglobin $(\mathrm{g} / \mathrm{dL})$ & $10.21^{\mathrm{a}}$ & $10.68^{\mathrm{b}}$ & $9.59^{\mathrm{b}}$ & 0.07 \\
Red blood cell $\left(\times 10^{6} / \mathrm{mL}\right)$ & $9.07^{\mathrm{a}}$ & $9.42^{\mathrm{a}}$ & $8.23^{\mathrm{b}}$ & 0.01 \\
MCV (fl) & $28.03^{\mathrm{b}}$ & $26.98^{\mathrm{c}}$ & $30.95^{\mathrm{a}}$ & 0.04 \\
MCH (pg) & $11.49^{\mathrm{a}}$ & $11.70^{\mathrm{a}}$ & $10.61^{\mathrm{b}}$ & 0.04 \\
MCHC (g/dL) & $33.35^{\mathrm{a}}$ & $33.04^{\mathrm{a}}$ & $31.65^{\mathrm{b}}$ & 0.03 \\
White blood cell $\left(\times 10^{3} / \mathrm{mL}\right)$ & $7.99^{\mathrm{b}}$ & $9.78^{\mathrm{a}}$ & $10.01^{\mathrm{a}}$ & 1.58 \\
Lymphocytes $(\%)$ & 94.36 & 94.88 & 95.06 & 0.05 \\
Neutrophils $(\%)$ & 4.28 & 4.03 & 4.75 & 0.07 \\
\hline
\end{tabular}

$\mathrm{MCV}=$ mean corpuscular volume, $\mathrm{MCH}=$ Mean corpuscular haemoglobin, $\mathrm{MCHC}=$ mean corpuscular haemoglobin concentration

a. b, c, Means within the same row with different superscripts differ significantly $(\mathrm{P}<0.05)$; $\mathrm{SEM}=$ Standard error of mean

Presented in Table 3 is the haematological parameter of growing rams fed mixture of bamboo leaves and neem seed cake as replacement for forage grass. It was noted in literature that significant changes in the haemetological parameters are good indicator for the assessment of the pathological and nutritional status of farm animals. The inclusion of bamboo leaves and neem seed cake as test diets in rams dietary treatments significantly $(P<0.05)$ influenced the haematological parameters of rams except lymphocyte and nuetrophile that were not significant $(P>0.05)$. The numerical values obtained for packed cell volume $(\mathrm{PCV})$ in rams were significantly $(\mathrm{P}<0.05)$ higher in test diet $\mathrm{TD}_{2}(30.06 \%)$ compared to test diet $\mathrm{TD}_{3}(27.93 \%)$ and the control diet $\mathrm{TD}_{1}(26.08 \%)$. The PCV values were within the normal levels (26-36\%) earlier reported for healthy sheep by Pampori (2003). This indicated that at the levels of bamboo leaves and neem seed cake inclusion in the test diets did not have any adverse effect on the functions of the cells. It could also be said that ram maintained on these diets had better nutritional qualities; hence they had low susceptibility to infections and nutritional stress. Rams fed treatment diets $\mathrm{TD}_{1}(10.21 \mathrm{~g} / \mathrm{dL})$ and $\mathrm{TD}_{2}(10.68 \mathrm{~g} / \mathrm{dL})$ had significant $(\mathrm{P}<0.05)$ higher haemoglobin $(\mathrm{Hb})$ compared to the rams on diet $\mathrm{TD}_{3}(9.59 \mathrm{~g} / \mathrm{dL})$. The slight significant reduction in rams on $\mathrm{TD}_{3}$ might perhaps be consequent upon the effect of some antiquality components acting together in the bamboo leaves and neem seed cake to induce haematopoiesis inhibition. The significant $(\mathrm{P}<0.05)$ higher variation that exist in red blood cell (RBC) of rams on treatment diets $\mathrm{TD}_{1}\left(9.07 \times 10^{6} / \mathrm{mL}\right)$ and $\mathrm{TD}_{2}$ $(9.42 \times 10 \% \mathrm{~mL})$ compared with $\mathrm{TD}_{3}(8.23 \times$ $10 \% \mathrm{~mL}$ ) could suggest their superiority in terms of their capability of supporting high oxygen carrying capacity in the blood and absence of anemia related diseases which might be due to iron deficiency. However, the slight low values observed in red blood cell of rams fed diet $\mathrm{TD}_{3}$, further attest the improper utilization of the diet for the formation of $\mathrm{Hb}$ that had greater affinity for iron by making them unavailable which reduces effective oxygen transpiration in the blood. Notwithstanding, the mean values of $\mathrm{Hb}$ and $\mathrm{RBC}$ recorded in this study were within the normal range of values for $\mathrm{Hb}(8.07$ to $11.70 \mathrm{~g} / \mathrm{dL})$ and $\mathrm{RBC}(5.00$ to 


\section{Performance and blood profile of rams fed mixture of bamboo leaves and neem seed cake}

$\left.11.00 \times 10^{6} / \mathrm{mL}\right)$ as indicated by several studies (Pampori, 2003; Taiwo and Ogunsanmi, 2003) for sheep. Mean corpuscular volume (MCV) that had no particular trend in variation was significantly $(\mathrm{P}<0.05)$ highest in $\mathrm{TD}_{3}$ (30.95fl) and lowest in $\mathrm{TD}_{2}(26.98 \mathrm{fl}) . \mathrm{MCV}$ is an important trait that determines the cell size of red blood cell and the ability of animal to survive in low oxygen conditions. Thus, the higher MCV observed in rams fed diet $\mathrm{TD}_{3}$ indicated that they could able to withstand prolonged oxygen starvation (Aruwayo et al., 2011). Mean corpuscular haemoglobin $(\mathrm{MCH})$ and mean corpuscular haemoglobin concentration (MCHC) were significantly $(\mathrm{P}<0.05)$ improved in diets $\mathrm{TD}_{1}(11.49 \mathrm{Pg} \& 33.35 \mathrm{~g} / \mathrm{dL})$ and $\mathrm{TD}_{2}$ (11.70Pg \& $33.04 \mathrm{~g} / \mathrm{dL})$ than $\operatorname{diet} \mathrm{TD}_{3}(10.61$ $\& 31.65 \mathrm{~g} / \mathrm{dL}$ ). These numerical depressed values for $\mathrm{MCH}$ and $\mathrm{MCHC}$ in diet $\mathrm{TD}_{3}$ corroborate the reduced $\mathrm{RBC}$ value observed in the same diet $\mathrm{TD}_{3}$. This further elucidated the inferiority. of the diet to test diet $\mathrm{TD}_{2}$. The reduction in the white blood cell (WBC) of rams on diet $\mathrm{TD}_{1}(7.99 \mathrm{x}$ $10^{3} / \mathrm{mL}$ ) reflects a decline in the production of defensive mechanism which naturally predisposes the rams to various physiological stresses due to disease and poor growth. Besides, the increase in the WBC of rams maintained on $\mathrm{TD}_{2}$ and $\mathrm{TD}_{3}$ showed an immunological response of the rams to foreign challenged. The similarity in high values of lymphocyte in this study is in line with the report of Opara et al. (2010) that high lymphocytes and WBC values are associated with the ability of animals to perform well under a very stressful condition. The non-significant $(\mathrm{P}>0.05)$ reduction in values of neutrophile among diets possibly explained the inclusion levels of the test diets that were tolerant and did not have inverse effect in the blood quality of the rams.

Table 4: Serum biochemical parameters of growing of rams fed experimental diets.

\begin{tabular}{lllll} 
Parameters & \multicolumn{3}{c}{ Treatment } & \multirow{2}{*}{ SEM } \\
\cline { 2 - 4 } & TD $_{1}$ & TD $_{2}$ & TD $_{3}$ & \\
\hline Total protein $(\mathrm{g} / \mathrm{dL})$ & $5.37^{\mathrm{b}}$ & $8.09^{\mathrm{a}}$ & $7.01^{\mathrm{b}}$ & 0.05 \\
Albumin $(\mathrm{g} / \mathrm{dL})$ & $2.34^{\mathrm{b}}$ & $3.03^{\mathrm{a}}$ & $2.95^{\mathrm{b}}$ & 0.01 \\
Globulin $(\mathrm{g} / \mathrm{dL})$ & $3.03^{\mathrm{b}}$ & $5.06^{\mathrm{a}}$ & $4.05^{\mathrm{b}}$ & 0.03 \\
Glucose $(\mathrm{mg} / \mathrm{dL})$ & $59.01^{\mathrm{a}}$ & $51.82^{\mathrm{b}}$ & $53.97^{\mathrm{b}}$ & 0.12 \\
Cholesterol $(\mathrm{mg} / \mathrm{dL})$ & $42.89^{\mathrm{a}}$ & $35.64^{\mathrm{b}}$ & $31.98^{\mathrm{c}}$ & 0.09 \\
Creatinine $(\mathrm{mg} / \mathrm{dL})$ & $1.08^{\mathrm{a}}$ & $0.79^{\mathrm{b}}$ & $0.91^{\mathrm{b}}$ & 0.04 \\
Urea (mg/dL) & $13.73^{\mathrm{a}}$ & $7.01^{\mathrm{c}}$ & $9.85^{\mathrm{b}}$ & 0.06 \\
\hline $\mathrm{a}, \mathrm{b}, \mathrm{c}$, Means within the same row with different superscripts differ significantly $(\mathrm{P}<0.05) ;$ &
\end{tabular}

$\mathrm{SEM}=\mathrm{Standard}$ error of mean

Table 4, shows the serum biochemical parameters of growing rams fed experimental diets. Blood contains myriad metabolites and other constituents, which provide a valuable medium for clinical investigation and assessment of nutritional status of animals. According to Waziri et al. (2010), serum biochemistry helps to investigate indications of gastro intestinal problems, immune suppression, productive organ problems and blood abnormalities. Parameters obtained for serum biochemistry were all significantly $(\mathrm{P}<0.05)$ affected by treatment diets. The mean values of total protein followed a particular trend with respect to mixture of 
bamboo leaves and neem seed cake content of the diets. However, total protein was influenced by increased in bamboo leaves with decreased in neem seed cake inclusion levels in the test diets which resulted in increased of total protein values by rams fed diet $\mathrm{TD}_{2}(8.09 \mathrm{~g} / \mathrm{dL})$ compared to those on diets $\mathrm{TD}_{1}(5.37 \mathrm{~g} / \mathrm{dL})$ and $\mathrm{TD}_{3}(7.10 \mathrm{~g} / \mathrm{dL})$. This suggests that the protein content of bamboo leaves and the combination with neem seed cake in $\mathrm{TD}_{2}$ positively influenced the protein utilization in rams which could probably responsible for the concomitant increased in the total protein values. Albumen and globulin were significantly $(\mathrm{P}$ $<0.05)$ lower in diets $\mathrm{TD}_{1}(2.34 \& 3.03 \mathrm{~g} / \mathrm{dL})$ and $\mathrm{TD}_{3}(2.96 \& 4.05 \mathrm{~g} / \mathrm{dL})$ compared with $\mathrm{TD}_{2}(3.03$ \& $5.06 \mathrm{~g} / \mathrm{dL})$ which was the highest. The reduction in total protein, albumin and globulin values observed in rams placed on diets $\mathrm{TD}_{1}$ and $\mathrm{TD}_{3}$ indicated abnormal alteration in systemic protein utilization which could be attributed on interference in protein synthesis. Furthermore, the higher levels of albumin and globulin observed in diet $\mathrm{TD}_{2}$ could be related to the nutritional adequacy and safety of the test diet which agrees with the report of Odunsi et al. (2009), that albumin synthesis in animals, is related to the amount of available protein present in the diets. Glucose values that did not follow any particular pattern of variation with respect to bamboo leaves inclusion in the test diets were significantly $(\mathrm{P}<0.05)$ highest among rams fed on treatment diet $T D_{\text {, with a mean }}$ value of $59.01 \mathrm{mg} / \mathrm{dL}$ followed by comparable values of $53.97 \mathrm{mg} / \mathrm{dL}$ and $51.82 \mathrm{mg} / \mathrm{dL}$ recorded among rams maintained on diets $\mathrm{TD}_{3}$ and $\mathrm{TD}_{2}$ respectively. The elevation in the level of glucose in $\mathrm{TD}_{1}$ might perhaps be ascribed to the influence of guinea grass utilization in the diet which could probably increase the energy content and subsequently improved glucose level in the rams. Several researchers (Daramola et al., 2005; Ogbuewu et al., 2011) reported that concentration of serum glucose is directly associated with energy utilization and metabolism in animal's body. Serum cholesterol values of $42.89,35.64$ and $31.98 \mathrm{mg} / \mathrm{dL}$ were recorded among rams on diets $\mathrm{TD}_{1}, \mathrm{TD}_{2}$ and $\mathrm{TD}_{3}$ respectively. The cholesterol levels declined progressively with increased levels of neem seed cake inclusion in the diets. This implies that serum cholesterol synthesis, metabolism and utilization were directly affected by the test diets although values observed were still within the range values (30.15 $82.08 \mathrm{mg} / \mathrm{dL}$ ) reported by Waziri et al. (2010). In addition, this observation agree with the similar findings of Ogbuewu et al. (2011) who noted that administration of the mature neem leaf extract concentration decreased serum cholesterol significantly without changing serum protein, blood urea and uric acid levels in rats.

Creatinine is formed when feed is changed into energy through the process called metabolism and it is muscle mass dependent. Its increase is an indication of the damage that might have been done to the kidney, hence, it is noted that high level of creatinine could lead to tissue wastage. The significant highest $(\mathrm{P}<0.05)$ value of creatinine was recorded in rams on $\mathrm{TD}_{\text {, }}$ $(1.08 \mathrm{mg} / \mathrm{dL})$ compared to rams on $\mathrm{TD}_{2}$ $(0.79 \mathrm{mg} / \mathrm{dL})$ and $\mathrm{TD}_{3}(0.91 \mathrm{mg} / \mathrm{dL})$. Notwithstanding, the creatinine values in this study did not exceed the normal range values of 0.6 to $2.5 \mathrm{mg} / \mathrm{dL}$ as reported by Taiwo and Ogunsanmi (2003). This implied that the test diets used in this study had no tendency to damage the nephron which could result into nephropathy. Serum urea was significantly $(P<0.05)$ influenced by treatment diets with rams on $\mathrm{TD}_{1}(13.73 \mathrm{mg} / \mathrm{dL})$ recorded the highest 
values followed by those on $\mathrm{TD}_{3}$ ( $9.86 \mathrm{mg} / \mathrm{dL})$ before $\mathrm{TD}_{2}(7.01 \mathrm{mg} / \mathrm{dL})$. The increase in serum urea level in rams placed on diet TD, might perhaps be ascribed to the effect of some endogenous anti-quality components which could probably reduces protein utilization owing to increase amino acid catabolism which were subsequently degraded into urea. This is in conformity with the report of Omoikhoje et al. (2003) that urea is an indirect measure of protein utilization in animals.

\section{Conclusion}

The study showed that feeding bamboo leaves with need seed cake to rams has potential of meeting the nutritional needs to rams in terms of basal diet. The response in terms of improved body weight gain and blood characteristics by growing rams indicated that mixture of $50 \%$ bamboo leaves with $20 \%$ neem seed cake can serve as the best sustainable feeds for rams most especially during the dry season.

\section{References}

Adjorlolo, L. K. Adjorlolo, Timpong Jones, E. C., Boadu, S. and Adogla - Bessa, T. 2016. Potential contribution of neem (Azadirachta indica) leaves to dry season feeding of ruminants in West Africa. Livestock Research for Rural Development 28(5): 261-268.

Agiang, E. A., Ayuk, A. A., Nweke, J. B. and Ozegbue, H. O. 2004. Performance of broilers fed diets with graded levels of cassava waste meal as energy source Journal of Agriculture and Food Science 2(1): $13-19$.

Ahamefule, F. O. and Udo, M. D. 2010. Performance of West African Dwarf goats feed raw or processed pigeon pea (Cajanus cajan) seed meal based diets. Nigeria Journal of Animal Production 37 (2): 227 236.

Antwi-Boasiako, C., Coffie G. Y. and Darkwa, N. A. 2011. Proximate composition of the leaves of Bambusa ventricosa, Oxytenanthera abyssinica and two variets of Bmbusa vulgaris. Scientific Research and Essays 6(34): 6835-6839.

AOAC, 1990. Official method of analysis, 15th ed. Association of Official Analytical Chemist. Washington DC., USA. *

Aruwayo, A., Maigandi, S. A., Malami, B. S. and Daneji, A. I. 2011. Haematological and Biochemical Parameters of Uda lambs fed graded levels of Alkali - treated neem kernel cake. Nigerian Journal of Basis and Applied Science 19(2): 277-284.

Bawa, G. S., Orunmuyi, M., Agbayi, A. S., Ladan, Z. and Okekeifi, U. O. 2007. Effect of different methods of processing Neem (Azadirachta indica) seed on performance of young rabbits. Pakistan Journal of Nutrition 6(3): 212-216.

Chandrawathani, P., Chang, K. W., Nurulaini, R., Waller, P. J., Adnan, M., Zaini, C. M., Jammah, O., Khadijah, S. and Vincent, N. 2006. Daily feeding of fresh neem leaves (Azadirachta indica) for worm control in sheep. Tropical Biomedicine 23(1): 23 30.

Daramola, J. O., Adeloye, A., Fatoba, T. A. and Soladoye, A. O. 2005. Haematological and biochemical parameters of West African Dwarf Goats. Livestock Research for 
Rural Development 17(8): 31-37.

Gbore, F. A., Ogunlade, J. T., Ewuola, E. O. and Egbunike, G. N. 2010. Growth indices and haematological parameters of weanling pigs fed dietary Fumonisi B. Nigeria Journal of Animal Production 37(1): 123-134.

Ghimeray, A. K., Jin, C. W., Ghimire, B. K. and Cho, D. A. 2009. Antioxidant activity and quantitative estimation of azadirachtin and nimbin in Azadirachta indica. A Juss grown in foothills of Nepal. African Journal of Biotechechnology 8 (13): 13084-3091.

Gowda, S. K. and Sastry, V. K. B. 2000. Neem (Azadirachta indica) seed cake in animal feeding - scope and limitations - review. Asian Australia Journal of Animal Science 13: 720-728.

Ikhimioya, I. and Imasuen, J. A. 2007. Blood profile of West African Dwarf Goats fed Panicum maximum supplemented with Afzelia africana and Newbouldia laevis. Pakistan Journal of Nutrition 6(1): 79-84.

ITTO (International Tropical Timber Organisation), 2009. Gifts from the forest international tropical timber organization technical series 32, Yokohama, Japan, Pp. 15.

Jain, N. C. 1986. Schalms Veterinary Haematology $4^{\text {th }}$ ed., Lea and Febiger, Philadelphia, USA.

Odunsi, A. A., Adegbile, S. A., Akande, T. O. and Olayeni, T. B. 2009. Neem (Azadirachta indica) seed cake in the diets of cockerel chickens. International Journal of Poultry Science 8(1): 47-51.
Ogbuewu, I. P., Odoemenam, V. U., Obikaonu, H. O, Opara, M. N., Emenalom, O. O., Uchegbu, $M$. C., Okoli, I. C., Eseonu, B. O. and Iloeje, M. U. 2011. The growing importance of neem (Azadirachta indica) in agricultural indusrry, medicine and environment : A review. Research Journal of Mechanical Plants 5(3) : 230 245.

Ogunsanmi, A. O., Akpavieso, P. A. and Anosa, V. O. 1984. Serum Biochemical Changes in WAD sheep experimentally infected with Trypanosoma brucei, Tropical Veterinarian 47(2): 195.

Omoikhoje, S. O., Arijeniwa, A. and Omueti, J. O. 2003. Physiological response of growing rats to processed bambara groundnut based diets. Haemtology and serum chemistry. Tropical Animal Production Investigations 6: 157 164.

Opara, M. N., Uderi, N. and Okoli, I. C. 2010. Haematological parameters and bloodehemistry of apparently healthy West African Dwarf (WAD) Goats in Owerri, SouthEastern Nigeria. New York Science Journal3(8): 68-72.

Pampari, Z. A. 2003. Field Cum laboratory procedure in animal health care Daya Publish House, New Delhi, India. Pp. 172-182.

SAS, 1999. Statistical Analysis System SAS User's Guide. Cary, NY: SAS Institute.

Schalm, O. W., Jain, N. C. and Carrol, E. J. 1975. Veterinary Haematology. $3^{\text {rd }}$ edition, Lea and Febiger, Philadelphia, USA. Pp. 160-210. 
Performance and blood profile of rams fed mixture of bamboo leaves and neem seed cake

Taiwo, V. O. and Ogunsanmi, A. O. 2003. Haematology, Plasma, whole blood and erythrocyte biochemical values of clinically healthy captive reared grey duicker (Sylviccapra grimmia) and West African dwarf sheep and goats in Ibadan, Nigeria. Israel Journal of Veterinary and Medicine 58(1): 1-6.

Waziri, M. A., Ribadu, A. Y. and Sivachelvan, N. 2010. Changes in the serum proteins, haematological and some serum biochemical profiles in the gestation period in the Sahel goats. Veterinary Archive $80(2): 215-224$.
Yousuf, M. B. and Adeloye, A. A. 2011. Performance response of goats feed shed leaves (Vitellaria paradoxa, Gmelina arboea and Daniella oliveri) basal diets. Nigeria Journal of Animal Production 38(1): 99- 105.

Zehui, J. 2007. Bamboo and rattan in the world. China Forestry Publishing House $1^{\text {st }}$ ed Beijing. China. Pp 360 .

Received: $3^{\text {rl }}$ September, 2016 Accepted: $1^{s t}$ February, 2017 